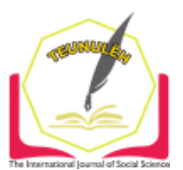

Jurnal Ilmiah Teunuleh

The International Journal of Social Sciences

Vol. 2, Issue. 2, June 2021

E-ISSN: $2746-4393$

\title{
SUPPLY CHAIN MODEL OF CAPTURE FISHERIES FOR FOOD SECURITY IN THE TIME OF THE COVID-19 PANDEMIC FOR INLAND COMMUNITIES OF WEST ACEH REGENCY
}

\author{
Y. Zuriat ${ }^{1}$; M. Rizal'; M. Ghazali ${ }^{3}$; Sabar Yuliana ${ }^{4}$ \\ ${ }^{1234)}$ Fisheries and Marine Science Department, Universitas Teuku Umar \\ Corresponding Author: zuriat@utu.ac.id
}

\begin{abstract}
Fish is one of the main ingredients of food security for the community. The factor of high and low levels of fish consumption is influenced by the distance to the fish landing center. West Aceh Regency, Aceh Province, has a territorial structure that stretches from the sea to the mountains. The study focuses on the level of supply (both kinds of as well as buying public power frequency) fish to the interior, by taking a sample that is the community and fish traders in sub district pantee ceremeun, West Aceh Regency. The results showed that there is no guarantee that fish will reach the hinterland every day, the supply of fish will arrive if the fish caught in the landing center of Ujong Baroh, Johan Pahlawan District, West Aceh Regency, are relatively abundant and cheap in price, with a short supply chain. Margin level reached 55\%. The fish supply chain from PPI Ujong Baroh which is the largest fish landing center in West Aceh Regency to remote areas which is 60 to $70 \mathrm{~km}$ away, so that the quality of the fish supplied is not fresh by dozens or about 45 fish agents (muge) using motorbike vehicles and tricycle rickshaws, with the difference in supply time occurring after 13.00 until 19.00 o'clock with an average fish price of $\mathrm{Rp} .31 .600$ perkilogram. Purchasing power of the community fish range 1 to 2 kilograms per household per week. In order to strengthen food security community, needs to be studied potential development and freshwater fish farming opportunities in rural areas.
\end{abstract}

Keywords: Supply Chain, Rural Communities, Margin and Food Security

\section{A. Introduction}

Aceh Province is one of the national fish barns, so that Aceh can be called the main fish-producing area in Indonesia in a sustainable manner whose management is integrated within the framework of the "SLIN National Fish Logistics System". To achieve this, it is necessary to design an ideal capture fishery supply chain management system 
in various areas of Aceh, including West Aceh Regency. Capture fisheries products in West Aceh Regency are the main focus of the community in meeting the needs of animal protein intake. The largest capture fisheries product landings in the West Aceh Regency were in two locations, namely at PPI Ujong Baroh and PPI Kuala Bubon. These various capture fishery products are landed every day except on Friday as the day of abstinence from the sea as stipulated in the customary law of the sea (laot-Aceh) by the panglima laot of West Aceh Regency.

In a previous reference written by Alfi Sahri R Baruadi, et al, with the title, "Model of Capture Fisheries Development Based On Minapolitan Concept In North Gorontalo District. The results of his research, the lack of production of fish catches is caused by the number of fishing fleets that are still lacking and do not increase so that fish production decreases, besides being influenced by the number of trips, it is also influenced by weather conditions or seasons. This is also influenced by the seasons which have an impact on the ability of the fleet and the effectiveness of fishing gear in catching fish caused by currents, strong winds and big waves. In the area of North Gorontalo Regency, the west season is an unfavorable season for fishing or is called the famine season.

The existence of the Fish Landing Port (PPI) which is located in an urban area and integrated into a traditional market area is a strategic location in the trading system of a commodity, especially in terms of marketing of fish caught by fishermen where the landed fish directly interact with traders and consumers. Marketing is the most important thing in running a fishery business because marketing is an economic action that affects the high and low income of fishermen.

The process of selling fish at PPI is that fishermen sell fish through toke or selected traders. Traders distribute fish to retailers or regions, both within the city, within the district and outside the district. The catch of fish originating from PPI which has a high selling value is reef fish. Reef fish have high economic value. The price is higher than other fish, so reef fish are mostly sold outside of West Aceh Regency, which means that they are not immediately sold to consumers who come to buy fish at PPI or by the people of Meulaboh City, but many are taken out of town. The outbreak of the Covid-19 virus, which has become a world pandemic, has not stopped fishermen's activities from going to sea. This is proven until now, fishery production is still running in the PPI West Aceh Regency. However, the condition of the Covid-19 pandemic is difficult for small-scale fishermen because the fish catches are not widely bought by the public. 
Supply Chain Model of Chapter Fisheries for Food Security in the Time of the Covid-19...

As a guide, the author also uses the next previous study written by Muhammad Rizqal Marwing, with the title, "The Impact of Covid-19 on Fishermen in the Coastal Area". The results of his research showed that several industrial sectors, including fisheries, were hit by the impact of the corona pandemic which was getting wider. Deployment

The impact of this disease is very much felt on the profession of fishermen and fishery workers. This can put great pressure on the socio-economic conditions of fishermen and fishing boat crews or fishery workers. The reduced number of operations and low market absorption are a blow to fishermen who live in coastal areas. For this reason, further identification is needed, including: (1). What factors affect the economy of the fishing community in the midst of the Covid-19 pandemic and why this impact can occur, (2). What are the policies taken by the government to resolve economic problems for small fishing communities and fishery workers in the midst of the Covid-19 pandemic?

In relation to the previous reference, it is necessary to observe how the fate of fishermen and fishery business actors, both small and large scale are currently facing a severe test in the midst of the Covid-19 pandemic, since the beginning of March 2020. This condition causes a decrease in fishermen's income due to unsold fish. and threaten the welfare of fishermen's families. The above fact is acknowledged by the Director General of Capture Fisheries of KKP-RI, which states that capture fisheries production continues, problems then arise because the fish caught cannot be absorbed by the market properly or there is an oversupply of fish throughout Indonesia. Fish production continues to be available at any time, but there needs to be a mechanism or system that can anticipate and deliver to consumers. On the other hand, currently many fish markets or fish processing units (UPI) in the West Aceh Region have not been running properly and the Cold Storage in PPI has not been optimally running. The impact of all that will trigger a decline in fish prices to reach a low range and result in fishermen who are smallscale fish producers forced to suffer huge losses.

Based on the above background, the researchers conducted a study on, "Supply Chain Model for Capture Fisheries Production for Food Security in the Covid-19 Pandemic Period for Inland Communities in West Aceh Regency". This study aims to protect West Aceh fishermen who have been affected by the Covid-19 pandemic, which is currently increasingly worrying. 


\section{B. Research Methods}

The implementation of this research was carried out in May - August 2021, whose data collection was located at the Fish Landing Port (PPI) of Ujong Baroh Village, Johan Pahlawan District, West Aceh Regency and inland areas of Pantee Ceremen District and Sungai Masi District in West Aceh District.

\section{Method of collecting data}

The data collection technique in this study is a survey method. The survey method is an investigation carried out to obtain facts from existing symptoms and seek factual information, both about social, economic, or political institutions of a group or an area (Nazir, 2005). The collection technique is through interviews using questionnaires, with two types of data, namely primary and secondary data and random simple sampling, the data collection is carried out in Mai to July 2021. Data were obtained from fish traders, in PPI Ujoeng Baroh and traders retailers who sell fish to the interior of West Aceh Regency, namely Pantee Ceuremen District and Sungai Mas District, West Aceh Regency.

\section{Data analysis}

Data processing is carried out by steps, namely editing, coding, tabulating, followed by mathematical calculations to obtain margin values, distribution volumes up to the final consumer. The capture fisheries supply chain management model uses Supply Chain analysis which is explained in the form of pictures, tables and graphs in detail. Then use margin analysis to find out the price difference between producers and final consumers, using margin analysis in the trading system (Hanafiah and Saefuddin, 2006). Margin value $=\mathrm{Hp}-\mathrm{Hk}$, where $\mathrm{Hp}$ : Producer Price and Hk: Price at the consumer level

\section{Results and Discussion}

Marketing is an important activity in running a fishery business, because marketing is an economic action that affects the rise and fall of fishermen's income. Production will be in vain when prices are low, so marketing must be good and efficient.

According to Triyanti and Safitri (2012), product marketing is one of the postproduction components that needs more attention in business development. Fishery products that are perishable, require that their marketing requires special attention. "Marketing channels have the task of distributing goods from producers to consumers. The length of the marketing channel will determine the quality of the product being marketed, namely costs, margins and marketing efficiency, as well as revenue. Fish 
marketing, especially in small-scale fisheries, often has not reached the ideal conditions", (Arinong and Kadir, 2008).

Good production will be wasted due to low market prices. High production does not absolutely provide great profits without good and efficient marketing. In general, marketing can be interpreted as all activities carried out by various intermediaries in various ways to convey production results, namely fresh marine fish, from producers to final consumers (Hanafiah and Saefudin, 2006). The amount of marketing profits and marketing costs at the intermediary level is a component in the formation of the final price (retail price) at the consumer level. This will affect prices at the producer level, and can even suppress prices at the producer level because the purchasing power of some consumers is still limited (Noviana, 2003).

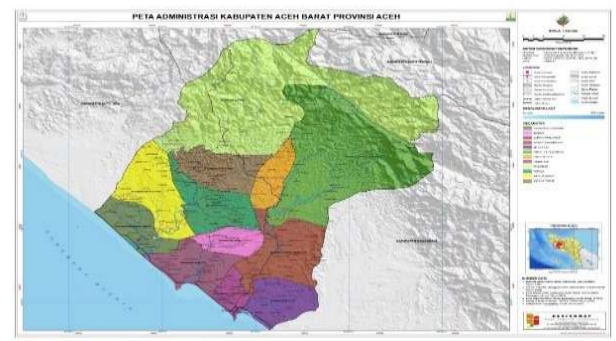

Picture. Map of West Aceh Regency as Research Location

The data collection process was divided into three groups. First, the data collection group for the target fishermen respondents. Second, the enumator group for data collection for traders. Third, data collection groups for rural communities. Field observations and observations were carried out in June 2021, at several points of the research area, namely at PPI Ujong Baroh, Fish Market in Sungai Mas and Pantee Ceureumen Districts, as well as several inland villages in two sub-districts, namely Sungai Mas District and Pantee Ceureumen District, Regency West Aceh. Due to the Eid al-Fitr holiday, data collection was extended until early June 2021. The purpose of this study was to trace the fish supply chain to inland communities originating from the catches of fishermen who landed through PPI Ujong Baroh, to further trace the level of fish margins reaching to rural communities.

The supply chain model for capture fisheries products from PPI UJong Baroh, to the final consumer, consists of 3 models, namely:

1. First from producers to interinsular traders, to wholesalers to the fish processing industry and to the general market 
2. Second, from producers to collectors, to traders outside West Aceh to the fish processing industry and to retail traders and end consumers.

3. From producers, to retailers and to consumers

The supply of fish to traders, households, restaurants, processing companies and other consumers is a trading process that is determined by time, facilities and prices as well as types of fish. The catch from the producer must remain fresh until it reaches the consumer, where the catch after reaching the consumer will be used as food for consumption, so it is very important for consumers to know how the food source is handled and distributed. "Flowing" the catch to another party can be called the distribution of the catch. Meanwhile, the distribution is according to the Decree of the Minister of Marine Affairs and Fisheries Number KEP. 01/MEN/2007, Ministry of Marine Affairs and Fisheries (2007), namely a series of activities for distributing fishery products from one place to another from production to marketing. The fish supply chain originating from PPI Ujoeng Baroh, there are several supply chain models as follows:

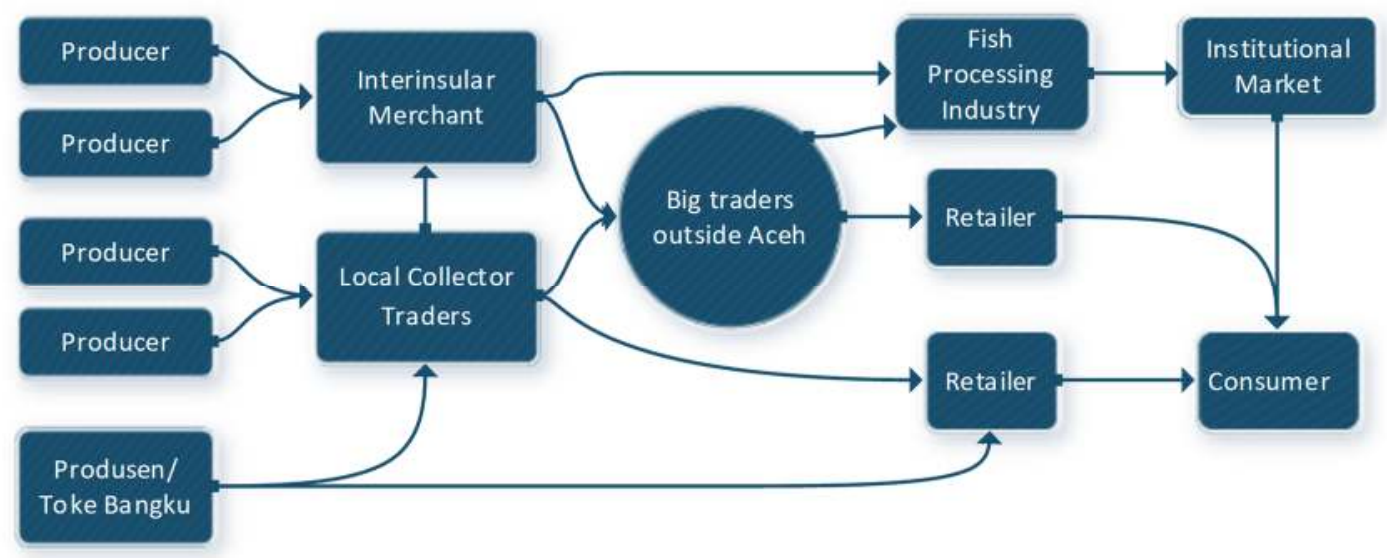

Figure: Supply Chain of Capture Fishery Products in West Aceh District

From the picture of the fish supply chain from PPI Ujoeng Baroh, it can be stated that fish from PPI Ujoeng Baroh is supplied to various regions, namely from local to outside areas outside Aceh, to Medan and Sibolga. Where outside Aceh is supplied for raw materials for fish processing plants, with chains from producers to inter-regional traders, collectors traders, then transported outside Aceh to various regions, and finally to the final consumer.

Meanwhile, the supply chain for the West Aceh Regency and the hinterland has a short chain of trade or the third model, namely from producers (fishermen, owners and 
Supply Chain Model of Chapter Fisheries for Food Security in the Time of the Covid-19...

bench shoppers) selling to retailers and retailers directly supplying to consumers, as shown in Figure 3 below.

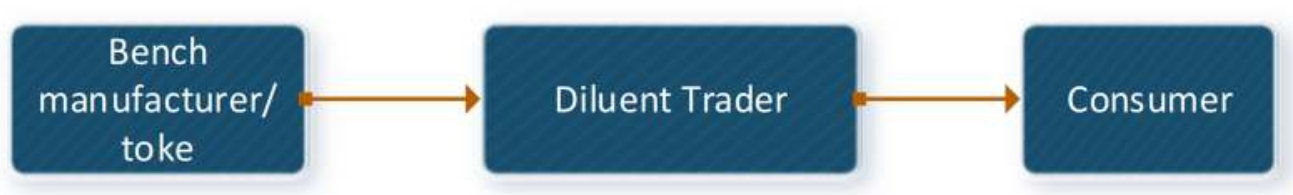

Image: Fish Supply Chain from PPI to the Interior

From the flow of the fish supply chain, it can be described, where the supply chain is short, but due to road conditions and the distance to the interior of up to $70 \mathrm{~km}$, it also affects various components in the trading system. For traders and consumers who supply fish to remote areas, they state that there is no difference in activities during Covid-19 and before Covid-19, where activities continue as usual and do not experience changes, but people's purchasing power decreases. "People's purchasing power has decreased due to the decline in people's economic income. This was acknowledged by Nurmawati from Jambak Village, Pantee Ceremen District and Rohani, a resident of Lamcong Village, Sungai Mas District.

The process of supplying fishery products, before reaching the final consumer, requires a series of activities which include: production, information gathering, sorting and grading, transportation, collection, storage, promotion and sales. In the marketing of a product or commodity, according to Limbong and Sitorus (1987), there are three groups that are directly involved, namely 1 ). Producer; 2). Intermediary agency; and 3). End consumer. In the field of fisheries, the producer group consists of fishermen and fish farming. The intermediary institutions in the fisheries sector consist of local collectors, inter-city collectors, wholesalers, retailers, and institutional markets. End consumers are parties who directly use or consume goods and services.

Retail traders are known as penggaleh Ungkoet. The third supply chain model, the results of researchers' observations can be classified into 2 groups of ungkot penggaleh, namely:

1. Door-to-door mobile retailer (PPKR), which can be classified according to the vehicle used, namely using a motorcycle, using a rickshaw to go out of town, to be supplied from house to house along the road that is passed to the hinterland or around the sub-district city. 
2. Permanent fish retailers (PPIM), namely: fish traders at PPI, around the Meulaboh City market road and at several points on the national road, and on the Regency road where they regularly sell retail fish every day.

The price of fish at PPI Ujoeng Baroh with inland areas, has a margin value of Rp. 11,600 or reaching $56 \%$, to be clearer, it can be seen in the table on the margin value of several types of fish during the pandemic in the interior of Aceh Regency as follows:

Tables. Trading margin by type of fish

\begin{tabular}{|c|l|r|r|r|}
\hline No & \multicolumn{1}{|c|}{ Fish Type } & \multicolumn{1}{c|}{$\begin{array}{c}\text { Price in } \\
\text { Manufacturer } \\
\text { (RP) }\end{array}$} & $\begin{array}{c}\text { Price consumed } \\
\text { (RP) }\end{array}$ & $\begin{array}{c}\text { Margin } \\
\text { (RP) }\end{array}$ \\
\hline 1 & Cakalang dan Sisek & 25.000 & 40.000 & 15.000 \\
\hline 2 & Tongkol & 20.000 & 30.000 & 10.000 \\
\hline 3 & Dencis & 15.000 & 25.000 & 10.000 \\
\hline \multicolumn{2}{|l|}{ Amount } & 60.000 & 95.000 & 11.600 \\
\hline \multicolumn{2}{|l}{ Average }
\end{tabular}

Source: Primary data 2021

From table 1 it can be seen that the price of fish sold to inland areas consists of 3 dominant types of fish, namely sissek or black tuna. Cobs and dencis or sardines. The highest price is sedge with an average selling price of Rp. 40.000 per/kilogram, and the lowest is sardines with an average of Rp. 25.000, the difference is Rp. 11.600,-

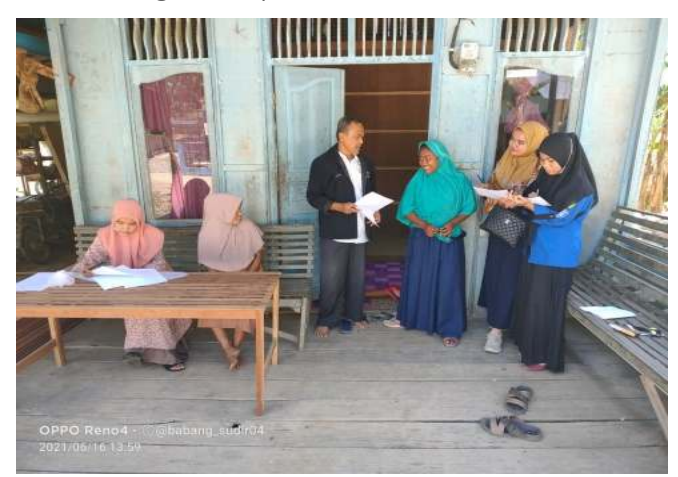




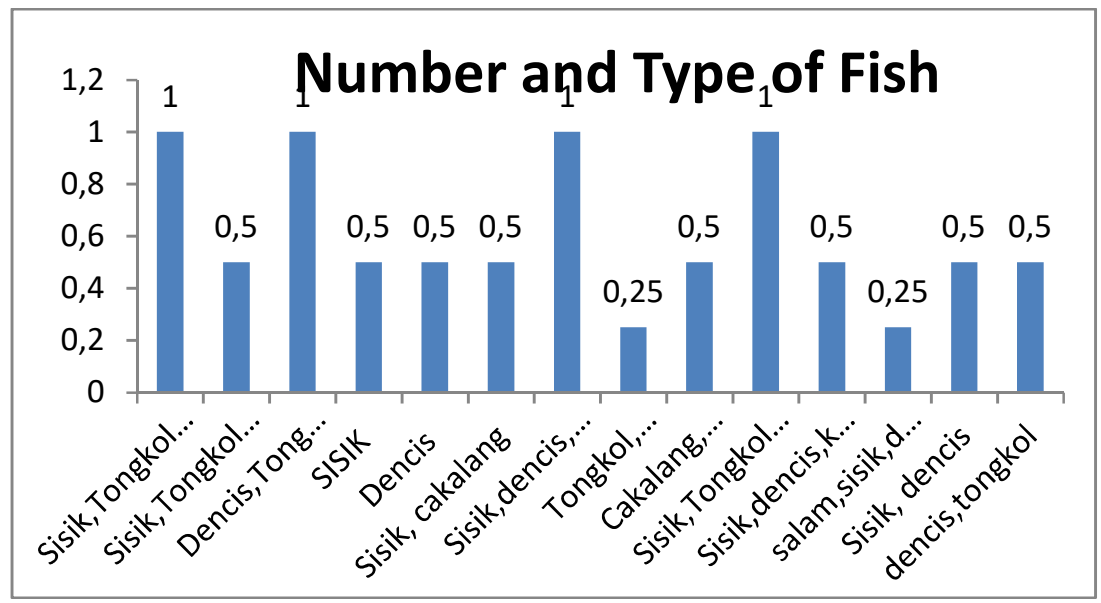

Picture. Number and type of fish

From Gambir 1, it shows that the graph of tuna, sissek and sardines dominates the supply and purchase of the community, where the amount of fish purchased is generally under 1 kilogram, which is an average of 500 grams in one fish purchase, with a shopping frequency of 2 to 3 times per week. . This small number of purchases is due to the low level of people's purchasing power, the quality of the fish is not fresh and the prices are relatively high for rural communities.

The price of fish is determined by the type of fish supplied, the highest fish price of the 3 dominant types of fish supplied is iken sisek or small tuna, and this fish is one of the fish that is in demand because it tastes better than tuna and sardines, followed by price of tuna and sardines

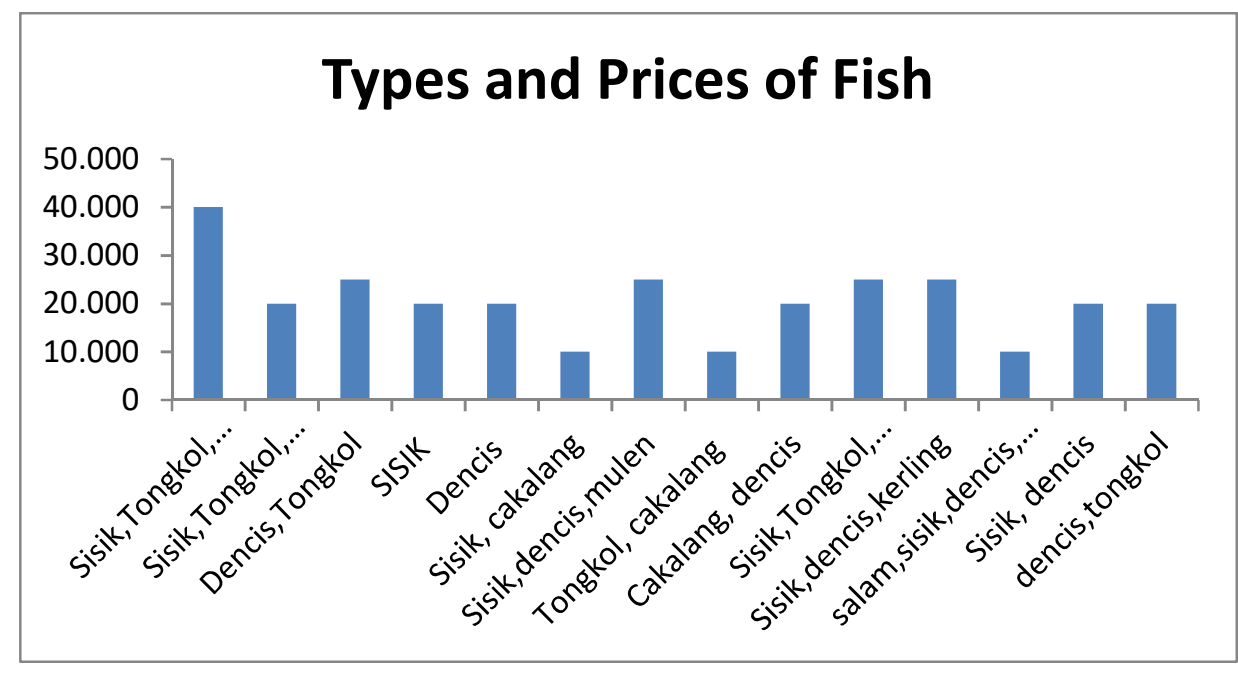

Picture. type and price 


\section{Margin Level}

The level of fishery product margin is determined by the price at the producer level in this case fishermen, toke bench and the selling price to inland consumers, as well as distance traveled, sales time and quality of fish. Margin level is as follows Price at producer level Rp. 15.000 Prices at the consumer level for rural communities Rp. 25.000. in accordance with the tables and graphs of Figures 9 and 10. From the table, an average margin of Rp. 11.600. According to Hanafiah and Saefudin (2006), the size of the margin value of the fishery trade system depends on the several factors, including: The distance between producers and consumers, whether or not the product spoils quickly, the scale of production, the financial position of the entrepreneur.

According to the researchers' observations and research, the dominant factor determining the supply of fish to remote areas is the consumer's financial position. The high supply of fish to consumers is usually because there are thanksgiving events, feasts and parties held by the community in the village. The magnitude of the price difference at the producer and consumer levels is largely determined by the purchase price, and the selling price. This condition is influenced by various factors, namely the time of purchase and sale, the scale of purchase, the type and quality of fish. The lower the quality of the fish, the lower the selling price to consumers and the distance traveled is also a major factor in the late arrival of fish to consumers. For rural people who are in the hinterland, of course, they have to spend more money than people who live in the city.

This was confirmed by the rural community, Jambak Village, Pantee Ceureumen District when interviewed. According to Insani and Darmi, the increase in fish prices so far may also be due to the corona pandemic. "As a result, we also feel the increase in fish prices because our living costs are mediocre. In addition, the supply of fish to our village is also limited, sometimes only two or three fish traders bring it to our village, and even then it arrives late in the afternoon", said the two housewives.

This condition is also experienced by the fish traders themselves, Muhammad Rijal for example. The 30-year-old man admitted that selling fish from house to house, departing from Meulaboh (Central Capital of West Aceh Regency), often starting at 13.00 $\mathrm{WIB}$, so that he arrived at the destination village around $16.00 \mathrm{WIB}$, even until 16.00 WIB. 18.00 . 


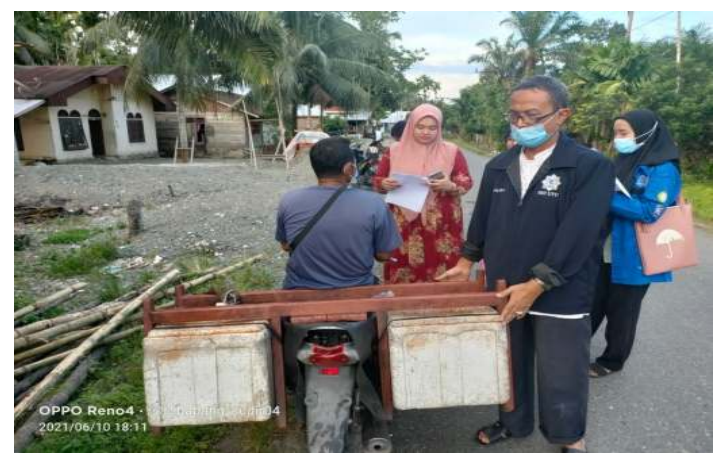

The results of interviews with residents of remote communities, including Mrs. Insani (aged 45 years) and Putro (50 years) residents of Jambak Village, Pantee Ceuremen sub-district, stated that the limitations in buying fish, among others, were due to the limited availability of funds, the price was also relatively high. Likewise, a Lamcong villager named Bu Darmi said the same thing that the supply of fish to the village was limited by two to three fish traders, and arrived in the afternoon. This right was justified by a fish trader named Rijal (aged 30 years), that because he started to go to sea selling fish from Meulabo, it's 13.00, with a door-to-door selling system, arriving in the hinterland is 16.00 to 18.00 .

The condition of Sungai Mas Subdistrict, Aceh Barat Regency, is a highway crossing to Pidie Regency, and there is a Fish Market at 3 (three) points along the Highway approaching the subdistrict. Meanwhile, the position of Pantee Ceureumen District is a suburb that crosses the mountain, so traders find it difficult and time limited in routinely supplying adequate amounts of fish.

\section{Conclusion}

1. That the supply of caught fish landed at PPI Ujong Baroh, Johan Pahlawan Subdistrict, Meulaboh, West Aceh Regency, generally takes place in the morning, and is supplied to remote areas from 13.00 to 19.00 hours, with consumption levels still low, namely the amount of 1 kilogram to 2 kilograms per week per household or an average of $24 \mathrm{~kg}$ per capita per year, with a purchase frequency of 1 to 2 times a week.

2. The supply chain model for inland fish is producers, toke bench, retailers and inland consumers, with fish species limited to tuna and dencis. Meanwhile, the quality of fish has decreased in freshness due to the relatively long time it takes for fish to arrive in the hinterland.

3. The level of margin, reaching more than 50 percent, with prices at the producer level ranging from Rp. 15,000 to Rp. 30.000, -, with various types of fish as well as variations in price and quality. 


\section{Recommendation}

1. The need for structuring the fish supply model to remote areas by establishing fish stock points by parties such as traders and the government.

2. The need for socialization to rural communities in strengthening food security.

3. It is necessary to conduct further research, regarding the study of the potential development of freshwater fish farming business, considering the potential of water resources in land in hinterland areas that have the potential.

\section{Bibliography}

(DPMP), D. P. (2006). Teknologi Untuk Pemberdayaan Masyarakat Pesisir. Jakarta: Departemen Kelautan dan Perikanan.

Adzani, F. (2020, Februari 24). Manfaat Omega 3, Lemak Tak Jenuh Yang Serba Bisa. Retrieved from SehatQ: https://www.sehatq.com/

Aliyas, Ndobe, S., \& Ya'la, Z. R. (2016). Pertumbuhan dan Kelangsungan Hidup Ikan Nila (Oreochromis sp.) Yang Dipelihara Pada Media Bersalinitas. Jurnal Sains dan Teknologi Tadulako, 5(1), 19-27.

Baruadi, A., Simbolon, D., Purbayanto, A., \& Yusfiandayani, R. (2017). Model Pengembangan Perikanan Tangkap Berbasis Minapolitan di Kabupaten Gorontalo Utara. Jurnal Teknologi Perikanan dan Kelautan, 3(1), 1-9. doi:10.24319/jtpk.3.1-9

Dewi, P. F., Widarti, I. G., \& Sukraniti, D. P. (2018). Pengetahuan Ibu Tentang Ikan dan Pola Konsumsi Ikan Pada Balita di Desa Kedonganan Kabupaten Badung. JURNAL ILMU GIZI : Journal of Nutrition Science, 7(1), 17-20.

Effendi, I. (2004). Pengantar Akuakultur. Jakarta: Penebar Swadaya.

Fakhruzzaman, A. (2010). Analisis Kelayakan Usaha Pembenihan Ikan Nila Gesit (Studi: Unit Pembenihan Rakyat Citomi Desa Tanggulun Barat, Kec. Kalijati, Kab. Subang Jawa Barat). Bogor: IPB (Bogor Agricultural University). Retrieved from http://repository.ipb.ac.id/handle/123456789/26753

Kasmir, \& Jakfa. (2003). Studi Kelayakan Bisnis (II ed.). Jakarta: Prenata Media Group.

KKP, A. (2015, Februari 16). Laporan Kinerja KKP 2014. Retrieved from KEMENTERIAN KELAUTAN DAN PERIKANAN: https://kkp.go.id/

Marwing, M. R. (2020). Dampak Covid-19 Terhadap Nelayan Diwilayah Pesisir Pantai. Retrieved from Academia.edu: https://www.academia.edu/

Meidiana Salsabila, H. S. (2018). Teknik Pembesaran Ikan Nila (Oreochromis Niloticus) di Instalasi Budidaya Air Tawar Pandaan. Journal of Aquaculture and Fish Health, 7(3), 118-123. doi:10.20473/jafh 
Supply Chain Model of Chapter Fisheries for Food Security in the Time of the Covid-19...

Rita Nurmalina, T. S. (2018). Studi Kelayaan Bisnis. Bogor: Departemen Agribisnis. Fakultas Ekonomi dan Manajemen. Institut pertanian..(2)2. Bogor. Bogor: IPB Press.

Sanusi, B. (2021). Pengantar Evaluasi Proyek. Jakarta: Universitas Indonesia.

Saparinto, C., \& Susiana, R. (2013). Sukses Pembenihan 6 Jenis Ikan Air Tawar. Yogyakarta: Andi Publisher.

Umar. (2003). Studi Kelayakan Bisnis. Jakarta: PT Gramedia Pustaka. 